\title{
"There is one thing we have learned from the Celtic Tiger years: Listen to the dissenting voice". An Interview with Martina Devlin
}

\author{
José Francisco Fernández \\ University of Almería, Spain
}

Copyright (c) 2019 by José Francisco Fernández. This text may be archived and redistributed both in electronic form and in hard copy, provided that the author and journal are properly cited and no fee is charged for access.

\begin{abstract}
Writer and journalist Martina Devlin was born in Omagh, in the North of Ireland, although she currently lives in Dublin. She worked in Fleet Street, London, and she now writes a weekly column for the Irish Independent. As a writer, her prizes include a Hennessy Literary Award and the V.S. Pritchett prize. In her novels she has dealt with events of the past: Ship of Dreams (2007), a novel about the Titanic, and The House Where it Happened (2015), a narrative based on a witchcraft trial in the 18th Century. However, in About Sisterland (2015) she imagines a future world ruled by women. Other titles include Three Wise Men (2000), Be Careful What You Wish for (2001), Venus Reborn (2003) and Temptation (2004). She is also the author of two non-fiction books, The Hollow Heart (2005), about her attempts at in-vitro fertilization, and Banksters (2009), co-autored with David Murphy, about the Irish banking collapse. In the present interview Devlin talks about Irish current affairs, about her work and in particular about her latest collection of short stories, Truth and Dare (2018). The conversation took place in February 2018 at Trinity College Dublin, where she is doing a MPhil in Anglo-Irish literature.
\end{abstract}

Key Words. Martina Devlin, literature, journalism, Northern Ireland, Irish current affairs, Irish politics.

Resumen. La escritora y periodista Martina Devlin nació en Omagh, Irlanda del Norte, aunque en el presente reside en Dublín. Durante un tiempo trabajó como periodista en Fleet Street, Londres, y actualmente publica una columna semanal de opinión en el diario Irish Independent. Entre sus galardones destacan el Hennessy Literary Award y el premio V.S. Pritchett. Su ficción se caracteriza por tratar temas del pasado, como en Ship of Dreams (2007), una novela sobre el Titanic, o The House Where it Happened (2015), una narración basada en un juicio por brujería en el siglo XVIII. Sin embargo en la novela About Sisterland (2015), imaginó un mundo futuro gobernado por mujeres. Otros títulos de su autoría son Three Wise Men (2000), Be Careful What You Wish for (2001), Venus Reborn (2003) and Temptation (2004). Además ha publicado dos libros de no ficción, The Hollow Heart (2005), 
sobre su experiencia con tratamientos de fertilización in-vitro, y Banksters (2009), un libro que escribió junto con David Murphy sobre el colapso del sistema bancario irlandés. En esta entrevista Devlin habla sobre asuntos actuales de política irlandesa, sobre su producción literaria, y en particular sobre su última publicación, el libro de relatos Truth and Dare (2018). Esta conversación tuvo lugar en febrero de 2018 en Trinity College Dublin, donde la autora cursa estudios de posgrado en literatura anglo-irlandesa.

Palabras clave. Martina Devlin, literatura, periodismo, Irlanda del Norte, asuntos de actualidad irlandesa, política irlandesa.

\section{José Francisco Fernández: Let's begin by talking about the relationship between journalism and literature.}

Martina Devlin: I switch between the two, sometimes on a daily basis. I don't have a problem with that. People say to me, “Are you a journalist or a writer?” And I say, I am a storyteller.

\section{JFF: When you write fiction, do you forget about the rest of the world?}

MD: Sometimes. Especially early in the week. But by Thursday I start paying attention to current affairs because I write a news analysis column on Friday for Saturday's Irish Independent. Every day I consume a long news bulletin, but that's in the evening, when I am tired and wouldn't be writing fiction anyway. Fiction is for the morning when I'm fresh.

\section{JFF: Do current affairs intrude in your writing?}

MD: In a roundabout way, I'll tell you an example. The House Where it Happened is set in the 18th century and About Sisterland is set in the 22nd century, but both have an issue in them concerning sexual consent. There is a news story running at the moment which is an attracting enormous amount of attention: it involves a court case in Belfast where a 19 year old girl is claiming she was raped by some well-known rugby players. She met them in a night club and went home with them afterwards to a party. The men admit there was sexual activity but insist it was consensual. It has given rise to a debate in society about how young men need to be educated on consent.

Consent is an issue in both novels. Reality informs your thinking when you are writing novels. In The House Where it Happened there is a sexual relationship between the master and the servant, and she doesn't have the right to say no, she would lose her job. The master convinces himself she is willing but she doesn't have a lot of choice. Or a lot of excitement in her life. In About Sisterland, the world is ruled by women and men have a much reduced status, used only for labour and procreation - they are called meets, a play on the word 'meat.' Fit specimens are obliged to mate with women chosen for them, in strictly controlled circumstances. That novel, though, is really about today, I think it is only nominally is it set in the 22 nd century. So that's a roundabout way for current affairs to come into my novels.

\section{JFF: I think there is a lot of Ireland in this novel.}

MD: To begin with, it is about Ireland because it is about communities which are kept apart. So it is specifically about Northern Ireland; I grew up there, and I was very conscious that the two communities could be civil to one another but they did not really interact. To my mind, 
extremism can take roots in the cracks where communities are kept apart. Those communities can be different religious groupings, different political affiliations, different genders, different classes, it doesn't matter which you choose for the purposes of the novel, but it is something which keeps people apart. So I chose gender as the difference in About Sisterland, but I could have easily gone for politics, class or religion.

JFF: You have mentioned your growing up in Northern Ireland and being conscious of the divide between both communities. Did you have the feeling that you were a secondclass citizen?

MD: I wanted to write about extremism in About Sisterland because I see extremism in the world around me. More extremism than there has ever been, with Brexit, Trump in the White House, the rise of the far right... When I grew up, yes, I was a second-class citizen and I was conscious of it. It wasn't as bad as in my father's time, but it still existed. When I was a young journalist and applied for work with a newspaper in Belfast, two minutes into the interview I was told, "Surely, Ms Devlin, culturally and socially you would be more at home in Dublin". The interview ended three minutes later. That's a way of saying you don't belong here. At that time (pre-Good Friday Agreement) legislation on equal opportunities in employment was weak: employers signed up to a voluntary code of practice and even that was not monitored. So they were going through the motions by having the interview and I felt very angry about that. I don't mean that I wanted to kick over dustbins but I wanted that society to change and I saw politics as the way to do it. Anybody who grows up in the North of Ireland realizes that politics can make a difference. The biggest news story of my life has been the Peace Process, and I am forever grateful to the Good Friday Agreement and the people who made it happen, because I know what it was like before.

JFF: In 2018 there was a celebration for the 20th anniversary of the Peace Process. In the ensuing debate, one of the topics was the role played by violence, particularly IRA violence, in the final outcome of the process. Would you have preferred history to be different?

MD: Yes, of course I would have preferred no violence. It was a devastating time. All of those deaths were needless: dialogue could have prevented the killing. But when we talk about violence let's be quite clear it wasn't just paramilitary violence causing problems, there was also state violence. I think it is wrong simply to talk about IRA violence. And I don't condone IRA violence; I think all killing is wrong, no human being has the right to take another one's life for any reason. But there were three types of violence, at least. There was IRA violence, loyalist violence and state violence. Imperial violence, the state's, has not been held accountable. The Irish government and political groupings in the North of Ireland, as well as victims and survivors of violence, would welcome a truth and reconciliation process for the real story to emerge. The British government will not agree and the reason it gives is national security. Basically, it was a very dirty war and the British government does not want the rest of the world to see some of the dirty deeds its agents got up to on its behalf during the Troubles.

Sometimes, it has had no choice but to admit to things. With Bloody Sunday, for example, although it delayed the reckoning by almost 40 years. The thing about Bloody Sunday, when civil rights protesters were shot by soldiers in 1972 in Derry, is that the British authorities attempted to rob the victims of their reputations as well as their lives. Not only were 14 people killed in a civil society protest against internment, which is imprisonment without trial and no release date, but afterwards they were smeared, labelled as terrorists. 
Some people still put forward that lie today. Last December, I was in England and someone said to me during conversation, quite casually, "Oh, but they were really IRA men who were shot on Bloody Sunday". And I said, "If that's the case, why did David Cameron as Prime Minister of Britain apologize publicly for what happened and call it a wrong?" Bloody Sunday prolonged the Troubles. The killings - an example of state-condoned violence - as well as the state-approved whitewash of an inquiry afterwards acted as a recruiting sergeant for the IRA. It was 2010 before Britain acknowledged the truth of Bloody Sunday following the Saville Report. There had been a tribunal in 1972, run by Lord Widgery, a former army officer, which exonerated the British Army and suggested some of the dead men had fired on soldiers or handled bombs. It was a lie. They were all innocent. Some of them were shot in the back running away. The soldiers, paratroopers, run amok among civilians in Derry and the British government defended their actions.

British people don't learn their own history, or if they do they only learn a narrow version, and I think that's a real problem. Many of them genuinely appear to believe that colonization was about bringing civilization to people of lesser worth. They are not educated on the negative side of empire - the asset-stripping, the suppression of native culture, the dehumanization process.

It's interesting to me, looking at the 1916-1922 period that I have been studying for my latest book, a short story collection, because when you read contemporary documents newspaper accounts, letters and so on - people are saying: "The Irish are disloyal" when the British need soldiers during World War I and Ireland refuses to accept conscription. Loyalty is not a right, loyalty must be earned. Yes, I think that growing up as a Catholic in the North of Ireland meant you were a second-class citizen, and for a woman of course it is a double disadvantage, because the question of equality is also a feminist issue as well. Women have had to fight very hard for equality.

\section{JFF: As a result of Brexit, you have openly advocated for reunification. Can you expand on that?}

MD: It think reunification is a realistic aspiration, but you have to make a good argument. It is not a convincing argument to say, Ireland was once united and therefore it must be reunificated again; that is not a compelling enough argument. You make one based on the best interests of the people and you can advance both an economic and a practical argument. We already have an All-Ireland energy market, for example, and the same applies to an agricultural market in real terms. It does not make sense to have a border on such a small island with six million people. We have more in common than divides us. But we have to recognise that the Unionist people on the island have a right to their views, there is no benefit in ramming them against their wishes into a united Ireland. We need to persuade them that they would be protected, supported and have opportunities within a united island. That everyone would benefit. That together we could be enriched culturally, politically and economically.

\section{JFF: How would you do that?}

MD: I would give them automatic seats in the Senate, the Second House, so they can have a platform and influence. I would also have unionist politicians co-opted into the Irish Cabinet from the Senate so they have power. We need to look at the Irish Constitution again and include an article within it that gives them protection. At the time of the formation of the Irish State, almost a century ago, they were rightly concerned that their civil liberties would not be respected in a Catholic, monocultural Ireland; they were correct to fear for them because the 
state which developed was quite repressive in some respects. It handed over too much control to the Catholic Church. So we have to make legislation that enshrines unionist rights and this can be done. We also need to respect one another's cultural differences. The former president, Mary McAleese, recognized this. I remember visiting the President's official residence, taking a tour as a member of the public, and we were led into her study and I was highly entertained to see a little soft doll of an Orangeman with a bowler hat and sash on a shelf. I thought, that's a promising sign because her family was driven out of their Belfast home by loyalist violence during the Troubles. She can forgive and forget. We all have a lot of forgiving and forgetting to do on both sides.

There is something that bothers me, though. I think it is a real problem that the border has become entrenched in people's minds after almost a century. Partition is now a state of mind. Some people on the Irish side, as well as the unionist side, see no value in unity. Or they fear it will cost them in terms of higher taxes. They need to be persuaded, too.

\section{JFF: At the present moment, in practical terms, the border does not exist, is that correct?}

MD: Yes, you only know you are across the border when a message pops up on your mobile phone telling you this is a roaming area. And when you see that the postbox is red, not green. The people are the same, the landscape is the same. People go back and forth across the border to shop, depending on the cost of goods and currency exchange rates. Many of us have relatives on both sides of the border and we go backwards and forwards visiting one another.

JFF: You have co-written a book (with David Murphy), Banksters, on the fall of the Irish economy in recent years. Has Ireland fully recovered from the crisis? Has Irish society learned from the experience?

MD: It was a dreadful experience. The economist David McWilliams put it very well when he said he belonged to a generation who might have to emigrate twice. I emigrated, I worked in London in my 20s, a common Irish experience. It's not necessarily a negative thing because you do gain a broader perspective. In Ireland we used to say we reared our children for the export market, the same as cattle, and the wonderful thing about the Celtic Tiger was there were jobs for everybody and a way to earn a living; there was full employment. And emigrants like me could home. But when the financial collapse happened, emigration was a reality again, and a country loses its young people that way.

\section{JFF: So the crisis is something of the past...}

MD: Well, the economy is roaring ahead, but can you trust it? We don't know. There aren't enough houses for everyone, property is very expensive, salaries are falling, there is a casualization of work contracts, and a huge problem of homelessness. We are told Ireland is on the up and up, but scars from the EU/IMF bailout experience remain in place. If there is one thing we have learned it is this: listen to the dissenting voice. During the Tiger years people who dissented were ridiculed or told they were being disloyal. Irish society wore the green jersey, Team Ireland, and those who refused to do so were dismissed as wrong or foolish. We know now we need contrary voices and I think the media has learned, as well, that it needs to be more sceptical about what officialdom tells it. As a columnist, I believe I should be independent, with a hint of the curmudgeon. It is very important not to be a victim of mental capture. Politicans, senior business people, policy makers, they have power, and 
when you meet them they can be extremely charming. But a little voice has to remain active in your head saying, "Stand back, don't be taken in. Look closer".

JFF: Has the crisis affected the feelings of the Irish people as regards the European Union?

MD: In general Ireland is pro-European; we do feel with some justification that being forced to re-pay junior bond holders was wrong. French and German banks would have suffered otherwise. So the European Union was giving more weight to French and German needs than to those of Irish citizens. They had us at a disadvantage; we were small and were squeezed. We value our European Union membership but we are aware that as little Ireland our voice isn't as loud as it needs to be at times. What I would say as the citizen of a small country is that we have never had an empire, we have never colonized another country, and that is something to take pride in.

JFF: How do you see your role as a journalist in times like the recent past of economic crisis in the country?

MD: I know that I am lucky to have a platform and I know that it is soft power because I don't have to stand for election. From the bottom of my heart I believe it is a position of trust, it's a contract between myself and the reader, I do my best to tell the truth as I see it, even if I make mistakes, even if I have prejudices. I try not to have prejudices and I cross-examine myself for them. But look, I'm human, I'm sure they appear, but I do my best to be fair. I hope readers will do me the courtesy of reading what I write, and disagreeing or agreeing but knowing I say what I do for the best possible motives and I am not in anyone's pocket. I feel extraordinary privileged to have the platform that I do. I take journalism very seriously and I know other writers also use and used the press to put their messages across. W.B. Yeats wrote for newspapers to get his message out to a wider audience as did George Orwell and Hemingway. It is a great vehicle that I take very seriously. Readers contact me often and I always try to reply.

JFF: Let's talk now about some of your books. I would like to ask you about The Hollow Heart. You decided to tell this story in a non-fictional form.

MD: I could have told that story as fiction, just as with Banksters (co-authored with David Murphy) - I could have written either book as a novel, and I thought about it. When I set out to tell a story I ask myself, "What is the best way to get my message across?" And with The Hollow Heart I thought personal testimony would work more powerfully than fiction, because with fiction people can always say, "That's just a story", whereas your own testimony has more reality. Before writing The Hollow Heart I was very struck by a sense that people believe modern medicine is a miracle and can cure all ills, but it can't and we have to accept that. IVF doesn't work for everyone. It didn't work for me. We have to come to terms with what life throws at us - it's how someone deals with setbacks that matters, in my opinion.

JFF: In that book you deal with a very intimate personal experience, weren't you afraid of exposing yourself too much?

MD: Of course. But I felt the fear and did it anyway. I really just wanted people to understand that fertility treatment is not something to embark on lightly and that it can have repercussions. I remember I was in a lift and I overheard two young women talking. One of 
them was saying, "I'd better have a baby soon, tick-tock", and the other one said, "Well, you could always have a fertility treatment". And my heart almost stopped. You know when your heart seems to pause and then kicks in again? And I wanted to tell them, it's not like going to the dentist! I didn't say anything then. I think I was too shocked. But by and by I decided I should describe my own experience. Just so people knew what they were getting into. The only stories that were out in the public sphere were stories about successful IVF - never when it failed. So people had unrealistic expectations.

One of the reasons I wrote the book was that you need counselling when you are considering or in the middle of infertility treatment. And there wasn't much counselling when I had the treatment. I remember just one, brief couselling session and it was formulaic, the couples I spoke to about it just said what they thought the counsellor needed to hear them, that box would be ticked and they would get through to the next stage. I feel very strongly that men, in particular, need counselling about the medical reality of what's happening to women because of the cocktail of drugs pumped into her. She is turned into a battery hen. She is put into a fake menopause and then powered up into hyper-fertility. Her body is terribly charged and so are her emotions, it's extremely stressful, and the man in these situations might think she's gone mad. I know that was the situation in our case. If someone could explain it's the drugs it would be helpful but nobody explained that in our case. You become illogical, driven, you can't see things in perspective. I am sorry I put so much effort into trying to change something that perhaps shouldn't have been changed in the first place. Why do we, as species, think we have the right to alter outcomes? At the same time, fertility treatments are wonderful and children have been born who wouldn't otherwise, and have brought so much joy into their family's lives. I don't regret that other women and men have been luckier than me with fertility treatments, everyone can't be lucky. I think the lesson I learned is acceptance. I try to to aim for stoicism, a quality I admire. I think it is a human quality that is underrated. I am not saying I am a stoical person but I do occasionally learn to accept what can't be changed.

\section{JFF: The diversity of your work is outstanding. Do you get bored after a particular book and feel the need to change for a different style?}

MD: It is not a question of boredom, it's not boredom at all, but I think the artist has the responsibility to stretch their own parameters. It would be too easy for me to keep writing books which are the same as the previous ones. I think the artist needs to at least attempt to encourage their readers to make a journey with them. To travel to places they might not have intended to go. William Golding said the writer should be a moving target and I share his philosophy. I accept that I may lose readers, but perhaps I may also gain some. I don't want to be a little old lady and look back on my life and say, "I didn't take chances". I'd like to think that by trying different genres and different means of getting my message across, perhaps one book in my whole body of work will have longevity - will outlast me. I don't know if that is possible but at least I'll try.

JFF: I wanted to ask you about Sisterland. Surely there was no coincidence that the book was published in the centenary anniversary of 1916. I liked the way it looks at the past and also at the future. It has echoes of Orwell's Ninety Eighty-Four and Huxley's Brave New World.

MD: And also of Charlotte Gilman Perkins's Herland. 


\section{JFF: Did you write the book having a political intention in mind?}

MD: Yes, it's about what happens when the oppressed becomes the oppressor. It originated in an Irish context but it has a universal relevance. The Irish context, for me, was the divided community which I grew up in, a divided society - I am from the North of Ireland and a child of the Troubles. But also I was thinking about the post-Good Friday Agreement era and how you have to forgive people. The Northern Irish state was an unjust and bigoted society. The model was state-authorised discrimination. But that was then and this is now. You have to let go of resentment.

I am really pleased that you see the link with 1916, from which we date the Irish state, because nobody has asked me about that and I left a clue with the name of my protagonist, Constance, because Constance Markievicz was one of the 1916 revolutionary leaders. The Irish state which developed after 1916 didn't live up to the reforming ideals of the revolutionaries. It became patriarchal, conservative, uber-cautious. The Catholic Church was allowed too much power and the hierarchy overreached itself to tell people how they should live. It was particularly controlling in relation to people's sexuality. Few are willing to accept that level of authoritarianism today but it has taken a series of child sex abuse scandals and cover-ups in the Catholic Church for its control to be diminished. It would, however, be ungenerous not to acknowledge the hard work done on the ground by nuns and priests in health and education. They have been let down by the Catholic leadership, too.

\section{JFF: Is it a case of Irish writing embedded in Irish history?}

MD: Usually with a book I do a large amount of research so I understand the subject really well. But with About Sisterland I gave myself permission to sit and stare into space. I just sat there thinking, What if? What if women ruled the world? How would that be for men? How would women behave towards men? Would they forgive them for all those centuries of being denied equality? What if they didn't - and treated men as second-class citizens? What if one woman wasn't prepared to go along with that? What if she said, "Society telling us how we should live and who we should love is wrong"? What if, really, that was my starting point.

But it does spring from an Irish perspective because of the two communities living on the northern part of this island who shared the same space but lived separately and "othered" one another. In the novel I made it "othering" beween two genders, but the important thing really is about oppressed and oppressor, followed by a reversal, an accommodation, and then having to learn to live together and work together afterwards. Learning to forgive one another matters enormously but it can be hard. In the North of Ireland, people have to forgive the violence - I know it's not easy, especially if someone you loved was killed - and the decades of discrimination against one section of the population.

What concerns me is mental distance between North and South. The border, as I mentioned earlier, is now in people's minds. It happened because of the violence - people were shamed by it. They thought it barbaric, which of course it was, but you can't take it out of context. Martin Luther King said a riot was the language of the unheard, and there was an element of that, too, in the bombing and shooting. I don't seek to justify it but to understand why it happened. But many in the Irish Republic simply turned their backs on the North of Ireland because they found it an embarrassment. The Troubles were on the news every night, bombs were going off, people were being killed. When peace came there was a sense of, okay, we can forget about it now. 


\section{JFF: Who are the contemporary Irish writers that you admire?}

MD: I suppose they tend to be writers that I am friends with, Ireland is such a small community that many of us know one another. I am vice-president of the Irish Writers Centre, which is a pro-bono position to give something back to my community. It helps writers professionally in their careers and provides them with a platform. I think it is important to be an advocate for your own community because it is very hard for writers to earn a living. It's not a coincidence that I keep going with journalism too because there is so little money in writing fiction. Writers have to pay their electricity bills, just as other people do.

As regards writers I admire, one of them is a friend of mine called Lia Mills. Her most recent book is called Fallen (2014) and is set in 1916. She writes non-fiction as well - a memoir, and she's an extrememly good essayist. I feel we are on the same wave length. Actually, we talk about current affairs a lot. I am great friends with a children's writer, Sarah Webb. We live near one another, and go for walks and talk books. Then there is Catherine Dunne, who has written a large number of excellent novels, I think I must have read all of them. Currently she is writing a trilogy, the first one has been published, The Years that Followed (2016), inspired by Greek legends. David Park is another writer whose every book I read - he wrote The Truth Commissioner (2008), a title that fits his work because his writing always rings true. I also admire Joseph O'Connor: his fiction is quite, quite beautiful, but he can do humour too, not an easy gear change. I particularly admire the fact that he is supportive to other writers. The Thrill of it All (2014) and Star of the Sea (2004) are a couple of his titles that come to my mind. He's told me he's writing a book about Bram Stoker, author of Dracula, and I'll be first in the queue to buy that. Another writer I have to mention is Jennifer Johnson. She's a living legend, still writing in her nineties, isn't that inspirational? I studied her work as a student and now it's pinch-me territory to meet her as a fellow writer. And I can't leave out Louis de Bernieres, whom I meet occasionally - he's good fun and very clever. He's so proud of his children and often mentions them, which I like. We email each other from time to time. He always makes me laugh. Louis writes poetry and songs, and plays musical instruments - but we know him best for Captain Corelli's Mandolin (1994). He's read a couple of my books, I think he quite liked About Sisterland although maybe he was only being polite. I was talking to him recently about a new collection of short stories he's written, due out next year, and we thought it would be fun if we could do some events together because I've just had a short story collection published, Truth \& Dare.

\section{JFF: And what about the writers of the Irish tradition?}

MD: I am very interested in Somerville and Ross, currently I am doing research at Trinity College Dublin for a Ph.D. about them. They intrigue me for a number of reasons: because they were women, because they were feminists, because they were pushing against boundaries and because they were business-minded about their work. They were among the first to have a literary agent, James Pinker, from London, who also represented D.H. Lawrence, Henry James and Arnold Bennett. It was quite unusual at that time to have an agent. They wanted to earn a living from their writing, they were very shrewd ladies; they asked for royalties rather than a one-off payment because their books sold so well and they liked to sell a book's serialisation rights, too. They were second cousins and came from the Ascendancy class. I am interested in the Big House tradition although I don't come from it. If I had lived during that period I would have been a scullery maid. I think their reputation as writers suffers today because of their class but we have to find a place in modern Ireland for people of all traditions. 
Elizabeth Bowen is another writer I admire, and Kate O'Brien. Also William Trevor. Still, I am glad you asked me before about living writers first because one of the problems for writers working in Ireland today is the stultifying effect of dead giants like Beckett and Joyce. Theirs can be a freezing impact because so much attention is focused on them that you think, how am I to make my way as a contemporary writer? All you can do is put your shoulder to the wheel and keep going.

JFF: Your latest book, Truth \& Dare, consists of a collection of short stories in which the protagonists are significant women in Irish history. What is the origin of this project? Was it commissioned or was it something you felt the need to do?

MD: The idea for the book came to mind because this year is the centenary of the vote for women in Ireland and Britain. Women were allowed to vote in a general election for the first time in December 1918, as recognition of their contributions during World War I. This was a huge leap forward, although the franchise was not on the same terms as for men: women had to be over the age of 30 (compared with 21 for men) and have a university degree or be a property owner. But it was a start. In 1922, when Ireland gained independence, the vote was extended to women on the same basis as to men, a reform which happened eight years ahead of Britain. I felt a strong compulsion to mark this in some way and managed to persuade my publishers to take on the book when I had only one of the 11 stories written. So they agreed to it sight unseen. Just on the basis of me saying "You must do this, it's a landmark year and a way of directing attention to these extraordinary women". It's difficult to get short story collections published because they don't tend to sell as well as novels so they took a chance on me.

Also, the project is unusual in that it's a blend of fact and fiction - I reshaped real episodes from the lives of these women, fictionalizing them, inventing conversations and so on. I decided to tell their stories in this way, rather than as biography, because of the magic in fiction. It allows readers to walk in someone else's shoes. I hoped it might bring the women vividly to life for readers - as alive to them as they are for me. I admire them so much - their selflessness and idealism, as well as their practical streak, finding ways around obstacles. Many of the women I write about in Truth \& Dare were feminists, nationalists, writers and activists - they were an exceptional generation, idealistic and optimistic, and they dared to imagine a different world. They deserve to be celebrated. But their fate was to be pushed aside by the men they had worked alongside to win Irish Independence. Their former comrades marched ahead and left them behind.

\section{JFF: In the introduction you say "they are my heroes". We live in sceptical times, does modern society need inspiring? In what sense?}

MD: Every society needs heroes. And every generation, too. But I think women need to be reminded about them in particular because many pioneering women, women who rattled their cages and challenged the status quo (man-made rules for the benefit of men) have been obliterated from history - sometimes deliberately. The contributions made by earlier generations of women have been forgotten, minimized and sidelined. It's a misrepresentation of our past. And the past matters because we can learn from it. It can inspire us. The women I wrote about in the collection - people like Maud Gonne, Hanna Sheehy Skeffington, Countess Markievicz and Anna Parnell - didn't ask anyone's permission before they taking control of their own destinies; they just did it. Some of them were jailed for what they believed in but that didn't stop them. One of the lessons we can learn from them is the value of partnership - they supported one another. They also understood the value of education and 
pressed for admission to universities at a time when women were excluded from taking degrees. I see these women as sticks of dynamite because the repercussions from their actions reverberate still. I can vote, and attend college, and enjoy workplace protection because of them - I'm standing on their shoulders. That's why I call them my heroes. And they are.

Received: 30 August 2018

Accepted: 06 November 2018

José Francisco Fernández is Senior Lecturer in English literature at the University of Almería, Spain. His most recent work focuses on the narrative of Samuel Beckett and his reception in Spain, including articles on Beckett published in specialized journals such as Journal of the Short Story in English, Journal of Beckett Studies, AUMLA, Studi Irlandesi and Arcadia, among others. He has also translated into Spanish three novels and three short stories by Samuel Beckett. His translation of Texts for Nothing was awarded with the AEDEAN translation prize in 2016. He teaches Anglo-Irish literature in the Master's Degree in English Studies at the National Distance Education University (UNED) and is general editor of the journal Estudios Irlandeses.

jffernan@ual.es 